\title{
CONSERVATIVE FLUIDS AND LUBRICANTS BASED ON TURBINE OIL, NITRO, AMIDO AND PARAFFIN WAX
}

\author{
V. M. Abbasov, E. J. Aghazadeh, E. Sh. Abdullaev, E. K. Gasanov, L. I. Aliyev \\ Mamedaliev Institute of Petrochemical Processes, National Academy of Sciences of Azerbaijan, AZ1025 Baku, \\ Azerbaijan \\ E-mail address: abdullaev685@yahoo.com
}

\begin{abstract}
To create conservation fluids and lubricants based on the oil acids and polyethylene polyamine (PEPA) synthesized amidoamines, and based on a-olefins (C12, C14 and C16-C18) and the nitric acids-nitro compounds. Using of amido, nitro and solid n-paraffins in the turbine oil T-30 (Standard 32-74) formulated lubricants and conservation fluid which are tested under different conditions. It is shown that in comparison with the preservative fluid, the preservative lubrication more effective.
\end{abstract}

\section{Indexing terms/Keywords}

corrosion inhibitor, conserving fluid, lubricants, nitro- amido products, turbine oil, petroleum acid, polyethylene polyamine, a-olefin, a solid $n$-paraffin.

\section{Academic Discipline And Sub-Disciplines}

Corrosion protection

\section{SUBJECT CLASSIFICATION}

Chemistry Subject Classification

\section{TYPE (METHOD/APPROACH)}

Experimental study

\section{Council for Innovative Research}

Peer Review Research Publishing System

Journal: Journal of Advances in Chemistry

Vol 3, No. 1

editor@cirworld.com

www.cirworld.com, member.cirworld.com 
Mineral acids oil is used for protection of various metal products against atmospheric corrosion to be prolonged storage. However, the use of oil only slightly affects the rate of corrosion, so as the oil film formed on the metal surface even with large thickness transmits vaporized water in sufficient amounts to intensify the corrosion process. Therefore, to improve the anticorrosive properties of oils it is administered to use substances having inhibitory properties. By adding oil-soluble corrosion inhibitors created a number of conservation of liquids [1-3].

In this regard, the development of new chemical complex with protective actions today is virtually an urgent task.

In this work, the results of creation composite conservation of fluids and lubricates based on turbine oil, synthetic corrosion inhibitors (nitro and amido) and solid n-paraffins.

Previously, we investigated anti-corrosion compositions based on the waste turbine oil [4].

For this study, as component-solvent is taken for the un worked turbine oil (T-30) with appropriate regulatory requirements.

For the corrosion inhibitor, the following compounds have been used: -nitro compound synthesized based on a-olefins (C12, C14, and C16-C18 mixture), and nitric acid are readily soluble in the turbine oil (T-30) - Amidoamines synthesized on the basis of oil acids (TNCs) and polyethylene polyamine (PEPA), were taken in different molar ratios $(1: 1 \div 5: 1$, respectively).

The protective properties of the prepared conserved compositions were evaluated by a set of methods for simulating the effect of the corrosive environments on the protected surface, high humidity $(98-100 \%)$ and the temperature in the periodic condensation of moisture in the sea water and $0.001 \%$ solution of sulfuric acid.

The criterion for evaluating the protective properties of the conserved fluid and lubrications is the time (in days) of corrosion damages the surface plates of steel (CT-3) (\%).

Comparative data characterizing the efficiency of compositions based on nitro compounds of various molecular weights and amidoamines synthesized based on oil acids and PEPA taken at different molar ratios, are shown in Table 1.

When tested with the corrosion inhibitor, the fluid content was varied from 3 to $10 \%$.

As shown, the addition of amidoamines conservative liquid, significantly improves the corrosion resistance of conservation liquids. For example, turbine oil, without inhibitor the plate in hydrochamber corroded after 30 days (experiment 1), the oil content of the nitro compound (10\%) the corrosion process occurs only after 108 days (experiment 2 ). In the presence of amidoamines conservative liquids with anticorrosive properties the corrosion resistance is significantly increased and the plates are protected against corrosion up to 234 days (Fig. 1). It should be noted that the presence of amido conservative liquid increases effectiveness more than two times. Apparently the reason for the high result is a synergistic action between the nitro molecules and the amidoamine compounds.

From the data shown in Table 1, it was observed that the best result is achieved when the concentration of inhibitor 7 10\% (experiment 11 and 12).

In the sulfuric acid and seawater solution, the maximum protective action of the prepared compositions is obtained at 120 and 105 days, respectively.

The corrosion protective effect is also affected by the number of carbon atoms in the nitro molecules. The best results are achieved by $\mathrm{C} 14$. Therefore, further studies were conducted with nitro compounds based on the obtained $\alpha$-olefin $\mathrm{C} 14$. With further study of the composition of the conservative fluid injected amido the molar ratio of the nitro compounds was $1: 1$.

Later, in the composition of the conservative fluid was added $10 \%$ paraffin wax and tasted as conserving lubrication.

Tests were carried out in two ways. The first (I) method - lubricant is heated to a liquid state. At first the plate was tested for $5 \mathrm{~min}$ and maintained by dipping in a liquid. The second (II) method, the surface of plates is coated by thin layers of lubricants $(1-2 \mathrm{~mm})$. The test results are shown in Table 2.

From the comparative results shown in Tables 1 and 2 it can be observed that the conservative lubricants show better results. These differences are particularly noticeable when the surface of plates is coated by thin layers of lubricants.

Thus, the use of compositions in the form of conservation lubricant is more effective than conservative fluid. 
Table 1:The protective properties of conservative fluids based on nitro compounds and amidoamine compositions.

\begin{tabular}{|c|c|c|c|c|c|c|}
\hline \multirow[t]{2}{*}{$\begin{array}{l}\text { EXP. } \\
\text { № }\end{array}$} & \multirow{2}{*}{ Component } & \multirow{2}{*}{$\begin{array}{l}\text { The } \\
\text { composition of } \\
\text { conservative } \\
\text { fluid, } \%\end{array}$} & \multirow{2}{*}{$\begin{array}{l}\text { The total } \\
\text { concentration } \\
\text { of inhibitor in } \\
\text { the fluid, } \%\end{array}$} & \multicolumn{3}{|c|}{$\begin{array}{l}\text { Protective properties under test conditions(in } \\
\text { days) }\end{array}$} \\
\hline & & & & $\begin{array}{c}\text { hydrchamber } \\
\ll \mathrm{H}-4 »\end{array}$ & $\begin{array}{l}0.001 \% \\
\mathrm{H} 2 \mathrm{SO} 4\end{array}$ & Seawater \\
\hline 1. & Turbine oil (T-30) & 100 & - & 30 & 15 & 9 \\
\hline 2. & $\begin{array}{l}\text { Turbine oil (T-30) Nitro } \\
\text { compound }(\mathrm{C} 12)\end{array}$ & $\begin{array}{l}90 \\
10\end{array}$ & 10 & 92 & 21 & 47 \\
\hline 3. & $\begin{array}{l}\text { Turbine oil (T-30) Nitro } \\
\text { compound }(\mathrm{C} 14)\end{array}$ & $\begin{array}{l}90 \\
10\end{array}$ & 10 & 108 & 45 & 75 \\
\hline 4. & $\begin{array}{l}\text { Turbine oil (T-30) Nitro } \\
\text { compound }(\mathrm{C} 16-\mathrm{C} 18)\end{array}$ & $\begin{array}{l}90 \\
10\end{array}$ & 10 & 65 & 35 & 43 \\
\hline 5. & $\begin{array}{l}\text { Turbine oil } \\
\text { Amidoamines }\end{array}$ & $\begin{array}{l}97 \\
3\end{array}$ & 3 & 31 & 16 & 12 \\
\hline 6. & $\begin{array}{l}\text { Turbine oil (T-30) } \\
\text { Amidoamines } \quad(2: 1)\end{array}$ & $\begin{array}{l}95 \\
5\end{array}$ & 5 & 34 & 18 & 15 \\
\hline 7. & $\begin{array}{l}\text { Turbine } \\
\text { Amidoamines }\end{array}$ & $\begin{array}{l}93 \\
7\end{array}$ & 7 & 37 & 26 & 19 \\
\hline 8. & $\begin{array}{l}\text { Turbine oil } \\
\text { Amidoamines }\end{array}$ & $\begin{array}{l}90 \\
10\end{array}$ & 10 & 45 & 31 & 28 \\
\hline 9. & $\begin{array}{l}\text { Turbine oil (T-30) } \\
\text { Nitro compound } \quad(\mathrm{C} 14) \\
\text { Amidoamines } \quad(2: 1)\end{array}$ & $\begin{array}{l}97 \\
1,5 \\
1,5\end{array}$ & 3 & 170 & 63 & 47 \\
\hline 10. & $\begin{array}{l}\text { Turbine oil (T-30) } \\
\text { Nitro compound } \quad(\mathrm{C} 14) \\
\text { Amidoamines } \quad(2: 1)\end{array}$ & $\begin{array}{l}93 \\
2,5 \\
2,5\end{array}$ & 5 & 190 & 70 & 53 \\
\hline 11. & $\begin{array}{l}\text { Turbine oil (T-30) } \\
\text { Nitro compound } \quad(\mathrm{C} 14) \\
\text { Amidoamines } \quad(2: 1)\end{array}$ & $\begin{array}{l}93 \\
3,5 \\
3,5\end{array}$ & 7 & 202 & 120 & 105 \\
\hline 12. & $\begin{array}{l}\text { Turbine oil (T-30) } \\
\text { Nitro compound } \quad(\mathrm{C} 14) \\
\text { Amidoamines } \quad(2: 1)\end{array}$ & $\begin{array}{l}90 \\
5 \\
5\end{array}$ & 10 & 234 & 160 & 135 \\
\hline 13. & $\begin{array}{l}\text { Turbine oil (T-30) } \\
\text { Nitro compound } \quad(\mathrm{C} 14) \\
\text { Amidoamines } \quad(1: 1)\end{array}$ & $\begin{array}{l}90 \\
5 \\
5\end{array}$ & 10 & 115 & 78 & 61 \\
\hline 14. & $\begin{array}{l}\text { Turbine oil (T-30) } \\
\text { Nitro compound } \quad(\mathrm{C} 14) \\
\text { Amidoamines } \quad(3: 1)\end{array}$ & $\begin{array}{l}90 \\
5 \\
5\end{array}$ & 10 & 205 & 90 & 51 \\
\hline 15. & $\begin{array}{l}\text { Turbine oil (T-30) } \\
\text { Nitro compound } \quad(\mathrm{C} 14)\end{array}$ & $\begin{array}{l}90 \\
5\end{array}$ & 10 & 182 & 70 & 38 \\
\hline
\end{tabular}


ISSN 2321-807X

\begin{tabular}{|c|c|c|c|c|c|c|}
\hline & $\begin{array}{ll}\text { Amidoamines } \quad(4: 1)\end{array}$ & 5 & & & & \\
\hline 16. & $\begin{array}{l}\text { Turbine oil (T-30) } \\
\text { Nitro compound (C14) } \\
\text { Amidoamines (5:1) }\end{array}$ & $\begin{array}{l}90 \\
5 \\
5\end{array}$ & 10 & 161 & 65 & 38 \\
\hline 17. & $\begin{array}{l}\text { Turbine oil (T-30) } \\
\text { Nitro compound } \quad(\mathrm{C} 14) \\
\text { Amidoamines } \quad(2: 1)\end{array}$ & $\begin{array}{l}90 \\
5 \\
5\end{array}$ & 10 & 223 & 134 & 107 \\
\hline 15. & $\begin{array}{l}\text { Turbine oil (T-30) } \\
\text { Nitro compound } \quad(\mathrm{C} 16-18) \\
\text { Amidoamines } \quad(2: 1)\end{array}$ & $\begin{array}{l}90 \\
5 \\
5\end{array}$ & 10 & 226 & 137 & 109 \\
\hline
\end{tabular}

Note: the values in the brackets $(1: 1),(2: 1),(3: 1),(4: 1),(5: 1)$ are the molar ratio TOA: PEPA used in the synthesis process of amidoamines.

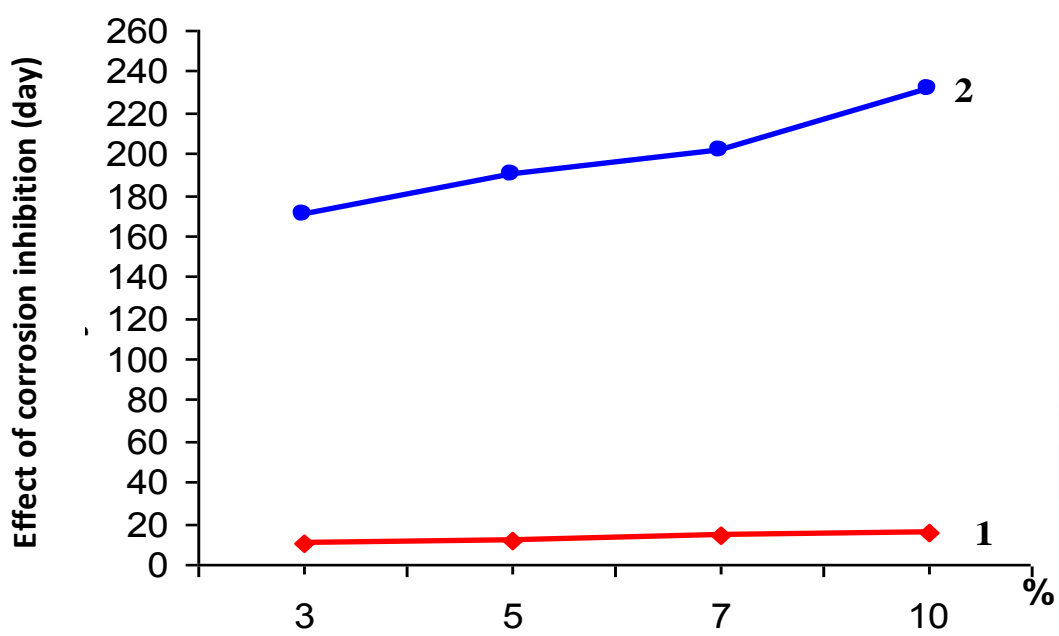

Figure 1: The dependence of the protective effect of the conservative composition of liquids in wet conditions.

1 - Turbine Oil T $30+$ amido (2:1)

2 - Turbine Oil T-30 + nitro compounds $\left(\mathrm{C}_{14}\right)+$ Amidoamine

Table 2: The protective properties of conservation-based lubricants, turbine oil, nitro, amido and paraffin wax

\begin{tabular}{|c|c|c|c|c|c|c|c|c|c|}
\hline \multirow{3}{*}{$\begin{array}{l}\text { EX } \\
\text { P. } \\
\text { № }\end{array}$} & \multirow{3}{*}{ Component } & \multirow{3}{*}{$\begin{array}{c}\text { The } \\
\text { composition } \\
\text { of } \\
\text { conservative } \\
\text { lubricants, \% }\end{array}$} & \multirow{3}{*}{$\begin{array}{c}\text { The total } \\
\text { concentrati } \\
\text { on of } \\
\text { inhibitor in } \\
\text { the } \\
\text { lubricants, } \\
\%\end{array}$} & \multicolumn{6}{|c|}{ Test conditions } \\
\hline & & & & \multicolumn{2}{|c|}{$\begin{array}{c}\text { hydrchamber «H- } \\
4 »\end{array}$} & \multicolumn{2}{|c|}{$\begin{array}{l}0.001 \% \\
\mathrm{H} 2 \mathrm{SO} 4\end{array}$} & \multicolumn{2}{|c|}{ Seawater } \\
\hline & & & & Met.I & Met.II & Met.I & Met.II & Met.I & Met.II \\
\hline & Turbine oil (T-30) & 80 & & & & & & & \\
\hline 1 & $\begin{array}{cc}\text { Nitro compound } & (\mathrm{C} 14) \\
\text { Amidoamines } & (1: 1) \\
\text { Parrafin } & \end{array}$ & $\begin{array}{c}5 \\
5 \\
10\end{array}$ & 10 & 191 & 197 & 81 & 86 & 44 & 53 \\
\hline 2 & $\begin{array}{l}\text { Turbine oil (T-30) } \\
\text { Nitro compound }(\mathrm{C} 14)\end{array}$ & $\begin{array}{r}80 \\
5\end{array}$ & 10 & 203 & 221 & 93 & 107 & 84 & 101 \\
\hline
\end{tabular}




\begin{tabular}{|c|c|c|c|c|c|c|c|c|c|}
\hline & $\begin{array}{c}\text { Amidoamines } \\
\text { Parrafin }\end{array}$ & $\begin{array}{l}5 \\
10\end{array}$ & & & & & & & \\
\hline 3 & \begin{tabular}{cc}
\multicolumn{2}{c}{ Turbine oil (T-30) } \\
Nitro compound $(\mathrm{C} 14)$ \\
Amidoamines \\
\multicolumn{2}{c}{ Parrafin }
\end{tabular} & $\begin{array}{c}80 \\
5 \\
5 \\
10\end{array}$ & 10 & 178 & 189 & 79 & 104 & 81 & 99 \\
\hline 4 & \begin{tabular}{cc}
\multicolumn{2}{c}{ Turbine oil (T-30) } \\
Nitro compound $(\mathrm{C} 14)$ \\
Amidoamines \\
\multicolumn{2}{c}{ Parrafin }
\end{tabular} & $\begin{array}{c}80 \\
5 \\
5 \\
10\end{array}$ & 10 & 163 & 171 & 41 & 52 & 39 & 51 \\
\hline 5 & $\begin{array}{l}\text { Turbine oil (T-30) } \\
\text { Nitro compound (C14) } \\
\text { Amidoamines } \\
\text { (5:1)Parrafin }\end{array}$ & $\begin{array}{c}80 \\
5 \\
5 \\
10\end{array}$ & 10 & 156 & 164 & 47 & 53 & 38 & 44 \\
\hline 6 & $\begin{array}{l}\text { Turbine oil (T-30) } \\
\text { Nitro compound (C12) } \\
\text { Amidoamines } \\
(2: 1) \text { Parrafin }\end{array}$ & $\begin{array}{c}80 \\
5 \\
5 \\
10\end{array}$ & 10 & 64 & 76 & 57 & 61 & 41 & 55 \\
\hline 7 & $\begin{array}{l}\text { Turbine oil (T-30) } \\
\text { Nitro compound (C16- } \\
\text { C18) } \\
\text { Amidoamines } \\
\text { (2:1)Parrafin }\end{array}$ & $\begin{array}{c}80 \\
5 \\
5 \\
10\end{array}$ & 10 & 71 & 77 & 56 & 64 & 39 & 52 \\
\hline 8 & $\begin{array}{c}\text { Turbine oil (T-30) } \\
\text { Nitro compound }(\mathrm{C} 14) \\
\text { Amidoamines } \\
\text { Parrafin }\end{array}$ & $\begin{array}{c}80 \\
5 \\
5 \\
10\end{array}$ & 10 & 189 & 204 & 79 & 83 & 68 & 72 \\
\hline 9 & \begin{tabular}{cc}
\multicolumn{2}{c}{ Turbine oil (T-30) } \\
Nitro compound $(\mathrm{C} 14)$ \\
Amidoamines \\
\multicolumn{2}{c}{ Parrafin }
\end{tabular} & $\begin{array}{c}80 \\
5 \\
5\end{array}$ & 10 & 224 & 231 & 103 & 112 & 98 & 105 \\
\hline 10 & \begin{tabular}{cl}
\multicolumn{2}{c}{ Turbine oil (T-30) } \\
Nitro compound & $(\mathrm{C} 14)$ \\
Amidoamines & $(2: 1)$ \\
Parrafin &
\end{tabular} & $\begin{array}{c}80 \\
5 \\
5 \\
10\end{array}$ & 10 & 237 & 239 & 126 & 133 & 114 & 121 \\
\hline
\end{tabular}

\section{CONCLUSION}

Thus, the results of these studies on creation of the technical fluids and lubricants for the conservation of metal parts and assemblies of mechanisms exploited in corrosive conditions found that the compounds based on turbine oil, nitro higher, linear olefins (C14), amidoamines and paraffin wax may be prepared by highly reagents. The introduction of the turbine oil into the above components allows increasing the cconservation term to 7-8 times under conditions of high temperature, humidity and 34 times in acidic medium and seawater. 


\section{REFERENCES}

[1] Zhang Qundan, Tian Songbai, Huang Shaokai, Wang Jing ( Res. Inst. Petr. Proces., China). Shiyou jiagong//Acta petrol sin Petrol. Prosess. Sec. 2012. 28, №4,p.652-656

[2] Panossian Zehbour, Almeida NeusvaldoLira de, Sousa Raquel Maria Ferreira de, Souza Pimenta Gutemberg de, Schmidt Marques Leandro Bordalo. Corrosion of carbon steel pipes and tanks by concentrated sulfuric acid. Corros. Sci. 2012.58,p.1-11.

[3] Abbasov V.M., AbdullayevE.Sh., Agazade E.Dzh., Gasanov E.K..Synthesis and research of preservation fluids on basis nitrocompounds and amidoamines. Mir nefteproduktov. $12 \# 2012$ p. 20.

[4] Liu Q.G., Yu X.Q.,Guo Y.S., Peng P.Y. Reliabilityassesment of pipeline in uniform corrosion conditions. Adv.Mater. Res.2011. 236,p.1628-1631.

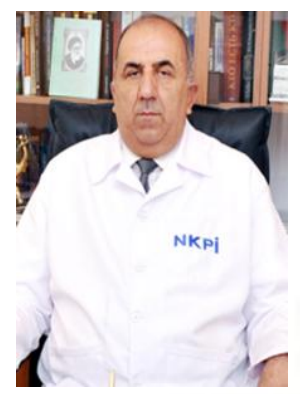

Prof. Dr. Vagif Maharram Abbasov Doctor of chemical sciences (DSC), Azerbaijan National Academy of Sciences, Institute of Petrochemical Processes, Director of Institute of Petrochemical Processes. He is a Member of the Editorial Board of "Processes of Petrochemistry and oil refining journal" (Chief Secretary). He is a Member of the American Chemical Society. He is an author on 250 papers in international journals and more than 35 books. V. M. Abbasov has carried out the thorough researches in the field of synthesis of antistatic additives to hydrocarbon liquids including to jet fuels. He for the first time proposed the possibility for producing the displaced complexes of nitroalkanes and organic acids with the transition metals, developed on their basis the high efficient and polyfunctional antistatic additive. This additive was tested and commercialized in perm plant of aircraft engines. V. M. Abbasov with coworkers has created in 1997 the polyfunctional waxy deposit corrosion inhibitor "Parkorin-1", the commercial tests have been carried out in the Azerbaijan oil fields, jointly exploited by Turkish- Azerbaijan and by TSNIIKP (Moscow city) has been recommended for application.

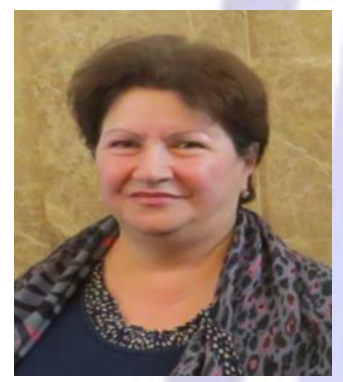

Prof. Dr. Leylufer Imran Aliyeva Doctor of Technical Sciences, Azerbaijan National Academy of Sciences, Institute of Petrochemical Processes, Head of department. She is a Member of the Editorial Board of "Processes of Petrochemistry and oil refining journal". She is an author on 220 papers in international journals and more than 18 books. Her work focused on the synthesis of nitroalkanes metallocomplexes, high-molecular amines and creation of polyfunctional antistatic additives, corrosion inhibitors, inhibitor-bactericides and study of their action mechanism. She has created the high efficient polyfunctional sulfurated hydrogen corrosion inhibitors based on $\alpha$-olifins with working capacity in the media with $\mathrm{H}_{2} \mathrm{~S}, \mathrm{CO}_{2}$ content more than $25 \%$ vol

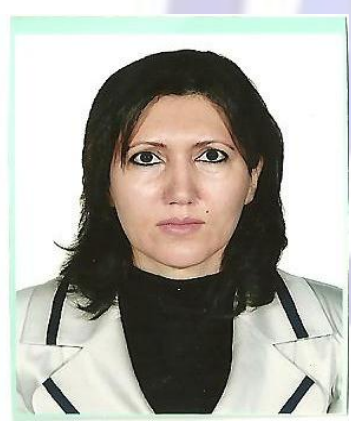

E. J. Aghazadeh is a Ph. D candidate in the Petrochemistry at the Mamedaliev Institute of Petrochemical Processes, National Academy of Sciences of Azerbaijan. She obtained Master degree of Science. Her research is focused on the Synthesis of various surfactants, compounds soluble in oils and fuels, and their investigation as corrosion inhibitors, additives to fuels, oils, polymeric stabilizers, development of theoretical bases for selecting corrosion inhibitors and additives

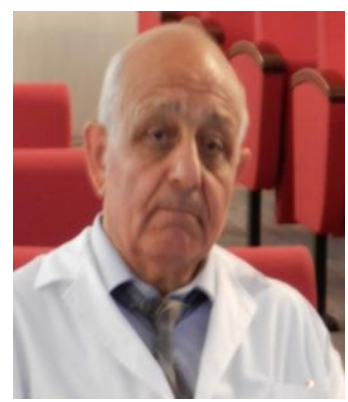

Prof. Dr. E. Sh. Abdullaev Doctor of chemical sciences, Azerbaijan National Academy of Sciences, Institute of Petrochemical Processes. He has more than 33 year's research experience in the field of Petrochemistry. He has published over 170 refereed articles in professional journals/proceedings. Dr. E. Sh. Abdullaev research has focused on alleviating problems associated with oil industry issues from corrosion. He is editor and reviewer of some international journals. 